\title{
HACE1, RAC1, and what else in the pathogenesis of SPPRS?
}

Han-Xiang Deng, MD, PhD

Neurol Genet 2019;5:e326. doi:10.1212/NXG.0000000000000326

Spastic paraplegia and psychomotor retardation with or without seizures (SPPRS) is a complex neurodevelopmental disorder with an autosomal recessive inheritance. SPPRS typically shows an infantile onset, starting with hypotonia either at birth or by age 3-4 months, followed by severely impaired global development and delayed early motor milestones. ${ }^{1}$ All patients with SPPRS develop slowly progressive bilateral lower limb spasticity, leaving them wheelchair bound and bed bound by their 20s. In some cases, patients may never walk. Most patients develop seizures in childhood and have a speech delay. Other variable features include ocular abnormalities, sensorineural hearing loss, skeletal abnormalities, obesity, and double incontinence. Some male patients have hypoplastic genitalia. Brain imaging may show generalized cerebral atrophy, ventricular dilatation, hypoplasia of the corpus callosum, and decreased white matter. ${ }^{1}$

By using family-based and unbiased genotype-driven whole-exome sequencing approaches, Hollstein et al. and Akawi et al. identified mutations of HACE1 in several patients with SPPRS. ${ }^{1,2}$ HACE1 encodes a HECT domain and ankyrin repeat-containing ubiquitin ligase (HACE1), which is involved in specific tagging of target proteins, leading to their subcellular localization or proteasomal degradation. Most HACE1 mutations in patients with SPPRS lead to a premature stop codon, suggesting that loss of HACE1 function causes SPPRS. However, the pathogenic mechanism remains largely unknown.

In this issue, Nagy et al. provide important information for understanding the pathogenic mechanism underlying SPPRS. ${ }^{3}$ They identified 2 novel homozygous truncating mutations in HACE1 in 3 patients from 2 families. More importantly, they performed detailed molecular and phenotypic analyses of Hacel knockout mice and SPPRS patient fibroblasts. They showed several clinical features in the Hacel knockout mice, which are similar to those observed in patients with SPPRS, including deficiencies in locomotion and learning/memory, enlarged ventricles, and hypoplastic corpus callosum. Pathologic and neurophysiologic studies demonstrated a reduced number of synaptic puncta and altered hippocampal synaptic transmission. The authors observed increased levels of active Racl in the Hacel knockout mouse brain and SPPRS patient-derived fibroblasts. RAC1 is a small GTPase with diverse roles in signaling, and HACE1 targets RAC1 to the ubiquitin/proteasome system for degradation. ${ }^{4}$ Therefore, the authors hypothesize that upregulation of the RAC1 pathway may underlie the pathogenesis of SPPRS because of defective degradation of RAC1 by HACE1 deficiency. This is the first in vivo study to show a molecular pathway underlying SPPRS.

A total of 11 mutations in 17 SPPRS cases have been reported to date. ${ }^{1,2,5}$ Except for a single amino acid deletion (p.Leu832del), all the others are truncation mutations. Although these truncation mutations presumably have almost identical functional consequences, great variations of clinical symptoms and disease severity were observed in these patients with SPPRS, suggesting that other genetic and environmental modifiers influence phenotype expression. It is known that the ankyrin repeats of HACE1 are responsible for substrate recognition, whereas the HECT domain is essential for ubiquitinylation. The p.Leu832del mutation is located in the

\author{
Correspondence \\ Dr. Deng \\ h-deng@northwestern.edu
}

RELATED ARTICLE

HACE1 deficiency leads to structural and functional neurodevelopmental defects

Page e330 
HECT domain, suggesting that the loss of ubiquitinylation activity, rather than the loss of the entire HACE1 protein, is critical for development of SPPRS.

Loss of HACE1 was initially noted in human malignancies, and Hace1 knockout mice were shown to develop spontaneous, late-onset multiple tumors after age 1 year. ${ }^{6}$ The tumor incidence was almost tenfold higher in the Hacel knockout homozygotes than the heterozygotes in 2-year-old mice (12\% vs $1.3 \%)$. Loss of Hace1 also rendered mice susceptible to second environmental and genetic hits for the development of multiple cancers. This led to the hypothesis that HACE1 is a tumor suppressor gene, which prevents tumorigenesis by suppressing cyclin $\mathrm{D}$ levels and reactive oxygen species generation. ${ }^{6,7}$ However, the neurodevelopmental phenotype and pathology in the Hacel knockout mice have not been comprehensively investigated until the present study.

The hypothesis that upregulation of the RAC1 pathway underlies the pathogenesis of SPPRS is compatible with the previous data. It is well known that RAC1 plays an essential role in development and structural plasticity of dendrites and dendritic spines. ${ }^{8,9}$ Transgenic mice overexpressing constitutively active RAC1 in Purkinje neurons lead to ataxia and reduced Purkinje neuron axon terminals and smaller but increased number of dendritic spines. ${ }^{8}$ Recently, heterozygous missense mutations in RAC1 were identified in developmental disorders with diverse phenotypes. ${ }^{10}$ Among 7 RAC1 mutations, p.Tyr64Asp appears to be constitutively active. The patient with this mutation showed some clinical features overlapping with those in SPPRS, including severely impaired global development and delayed early motor milestones, hypoplastic corpus callosum and genitalia, ocular abnormalities, and sensorineural hearing loss. However, marked differences were also observed. Notably, the patient with p.Tyr64Asp showed hypotonia soon after birth, but he did not seem to develop progressive spasticity, a specific feature in SPPRS, even by age 12 years. ${ }^{10}$ This may suggest that upregulation of RAC1 is one of the multiple pathways affected by the HACE1 deficiency in SPPRS.

Upregulation of RAC1 in SPPRS suggests a potential therapeutic approach by using specific pharmacologic inhibition of RAC $1 .{ }^{11}$ However, caution should be taken because the development and function of the brain requires RAC1 to be finely tuned, as shown by the observations that either loss (or dominant-negative effect) or gain of RAC1 function led to developmental disorders in humans, ${ }^{10}$ and both depletion and overexpression of Racl resulted in abnormal phenotypes in Xenopus laevis. ${ }^{12}$

Upregulation of RAC1 may explain a part of the clinical symptoms in SPPRS, but it does not cover the full spectrum.
This suggest that HACE1 may have other substrates. Indeed, HACE1 also regulates other small GTPases, including RAB11a, RAB6a, and RAB8a. ${ }^{13,14}$ It has also been reported that Hace 1 promotes the stability of Nrf2 and plays an important role in antioxidant response, and loss of hacel in a mouse model of Huntington disease accelerates motor deficits and exacerbates cognitive and psychiatric phenotypes. $^{15}$

The molecular mechanism by which increased RAC1 leads to the abnormal structure and function of synapses and the pathogenic roles of other HACE1 regulated proteins in the pathogenesis of SPPRS are still not understood. These issues remain to be addressed in future studies.

\section{Author contributions}

H.-X. Deng: drafting/revising the manusrcript.

\section{Study funding}

No targeted funding reported.

\section{Disclosure}

The author reports no disclosures. Full disclosures available: Neurology.org/NG.

\section{References}

1. Hollstein R, Parry DA, Nalbach L, et al. HACE1 deficiency causes an autosomal recessive neurodevelopmental syndrome. J Med Genet 2015;52:797-803.

2. Akawi N, McRae J, Ansari M, et al. Discovery of four recessive developmental disorders using probabilistic genotype and phenotype matching among 4,125 families. Nat Genet 2015;47:1363-1369.

3. Nagy V, Hollstein R, Pai T-P, et al. HACE1 deficiency leads to structural and functional neurodevelopmental defects. Neurol Genet 2019;5:e330. doi: 10.1212/ NXG.0000000000000330.

4. Torrino S, Visvikis O, Doye A, et al. The E3 ubiquitin-ligase HACE1 catalyzes the ubiquitylation of active Rac1. Dev Cell 2011;21:959-965.

5. Hariharan N, Ravi S, Pradeep BE, et al. A novel loss-of-function mutation in HACE1 is linked to a genetic disorder in a patient from India. Hum Genome 2018;5:17061.

6. Zhang L, Anglesio MS, O'Sullivan M, et al. The E3 ligase HACE1 is a critical chromosome 6q21 tumor suppressor involved in multiple cancers. Nat Med 2007;13: 1060-1069.

7. Daugaard M, Nitsch R, Razaghi B, et al. Hacel controls ROS generation of vertebrate Rac1-dependent NADPH oxidase complexes. Nat Commun 2013;4:2180.

8. Luo L, Hensch TK, Ackerman L, Barbel S, Jan LY, Jan YN. Differential effects of the Rac GTPase on Purkinje cell axons and dendritic trunks and spines. Nature 1996;379: 837-840.

9. Bongmba OY, Martinez LA, Elhardt ME, Butler K, Tejada-Simon MV. Modulation of dendritic spines and synaptic function by Rac1: a possible link to Fragile X syndrome pathology. Brain Res 2011;1399:79-95.

10. Reijnders MRF, Ansors NM, Kousi M, et al. RAC1 missense mutations in developmental disorders with diverse phenotypes. Am J Hum Genet 2017;101:466-477.

11. Martinez LA, Tejada-Simon MV. Pharmacological inactivation of the small GTPase Racl impairs long-term plasticity in the mouse hippocampus. Neuropharmacology 2011;61:305-312.

12. Iimura A, Yamazaki F, Suzuki T, Endo T, Nishida E, Kusakabe M. The E3 ubiquitin ligase Hace1 is required for early embryonic development in Xenopus laevis. BMC Dev Biol 2016;16:31.

13. Lachance V, Degrandmaison J, Marois S, et al. Ubiquitylation and activation of a Rab GTPase is promoted by a beta(2)AR-HACE1 complex. J Cell Sci 2014;127:111-123.

14. Tang D, Xiang Y, De Renzis S, et al. The ubiquitin ligase HACE1 regulates Golgi membrane dynamics during the cell cycle. Nat Commun 2011;2:501.

15. Ehrnhoefer DE, Southwell AL, Sivasubramanian M, et al. HACE1 is essential for astrocyte mitochondrial function and influences Huntington disease phenotypes in vivo. Hum Mol Genet 2018;27:239-253. 


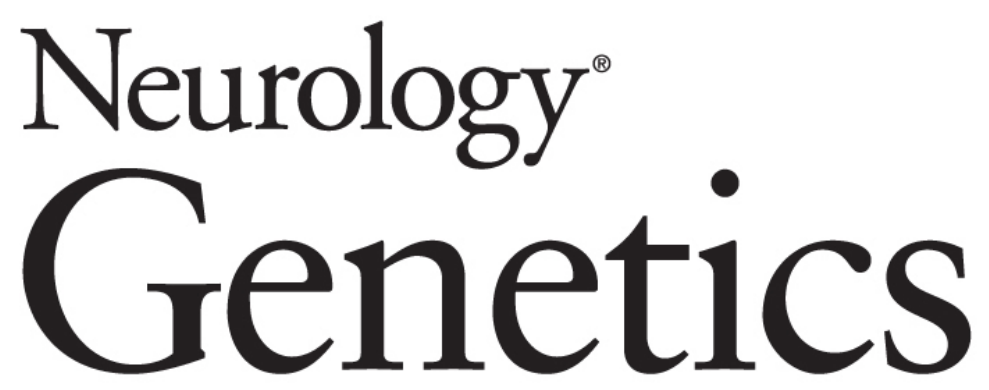

HACE1, RAC1, and what else in the pathogenesis of SPPRS?

Han-Xiang Deng

Neurol Genet 2019;5;

DOI 10.1212/NXG.0000000000000326

This information is current as of April 30, 2019

Neurol Genet is an official journal of the American Academy of Neurology. Published since April 2015, it is an open-access, online-only, continuous publication journal. Copyright Copyright ( 2019 The Author(s). Published by Wolters Kluwer Health, Inc. on behalf of the American Academy of Neurology.. All rights reserved. Online ISSN: 2376-7839.

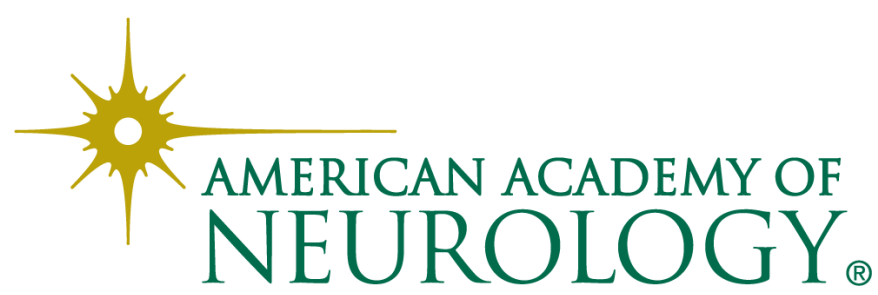




\section{Updated Information \& Services}

References

Subspecialty Collections

Permissions \& Licensing

\section{Reprints}

including high resolution figures, can be found at: http://ng.neurology.org/content/5/3/e326.full.html

This article cites 15 articles, 3 of which you can access for free at: http://ng.neurology.org/content/5/3/e326.full.html\#\#ref-list-1

This article, along with others on similar topics, appears in the following collection(s):

\section{All Genetics}

http://ng.neurology.org//cgi/collection/all_genetics

\section{Gait disorders/ataxia}

http://ng.neurology.org//cgi/collection/gait_disorders_ataxia

Intelligence

http://ng.neurology.org//cgi/collection/intelligence

Mental retardation

http://ng.neurology.org//cgi/collection/mental_retardation

Spastic paraplegia

http://ng.neurology.org//cgi/collection/spastic_paraplegia

Information about reproducing this article in parts (figures,tables) or in its entirety can be found online at:

http://ng.neurology.org/misc/about.xhtml\#permissions

Information about ordering reprints can be found online:

http://ng.neurology.org/misc/addir.xhtml\#reprintsus

Neurol Genet is an official journal of the American Academy of Neurology. Published since April 2015, it is an open-access, online-only, continuous publication journal. Copyright Copyright ( 2019 The Author(s). Published by Wolters Kluwer Health, Inc. on behalf of the American Academy of Neurology.. All rights reserved. Online ISSN: 2376-7839.

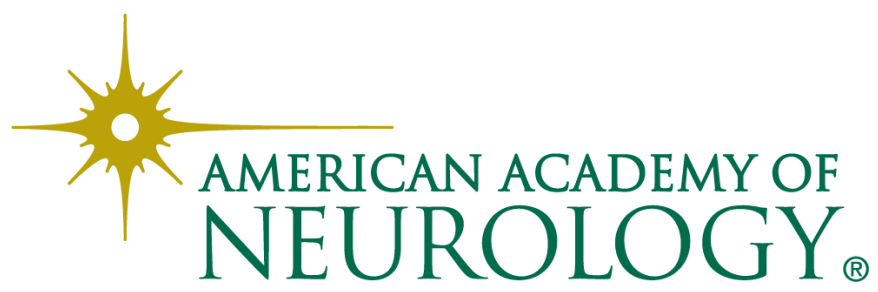

